\begin{tabular}{|l|l|l|}
\hline \multicolumn{2}{|c|}{ PublisherInfo } \\
\hline \hline PublisherName & $:$ & BioMed Central \\
\hline \hline PublisherLocation & $:$ & London \\
\hline \hline PublisherImprintName & $:$ & BioMed Central \\
\hline \hline
\end{tabular}

\title{
Patients with AMI continue to delay hospital presentation
}

\begin{tabular}{|l|l|l||}
\hline \multicolumn{2}{|c||}{ ArticleInfo } \\
\hline \hline ArticleID & $:$ & 26 \\
\hline \hline ArticleDOI & $:$ & $10.1186 /$ cvm-2001-72155 \\
\hline \hline ArticleCitationID & $:$ & 72155 \\
\hline \hline ArticleSequenceNumber & $:$ & 5 \\
\hline \hline ArticleCategory & $:$ & Paper Report \\
\hline \hline ArticleFirstPage & $:$ & 1 \\
\hline \hline ArticleLastPage & $:$ & 3 \\
\hline \hline & & RegistrationDate : 2001-1-18 \\
ArticleHistory & $:$ & Received $\quad: 2001-10-19$ \\
& $:$ OnlineDate $\quad: 2001-10-19$ \\
\hline \hline ArticleCopyright & $:$ & Biomed Central Ltd2001 \\
\hline \hline ArticleGrants & $:$ & \\
\hline \hline
\end{tabular}




\begin{tabular}{|l|l|l|l|l|l|l|}
\hline ArticleContext & $: 1306322$ \\
\hline
\end{tabular}

Joanna Lyford, ${ }^{\text {Aff1 }}$

Corresponding Affiliation: Aff1

Aff1 Medwire, U.K

\section{Keywords}

Acute myocardial infarction, myocardial reperfusion, patient admission

\section{Context}

Patients with acute myocardial infarction (AMI) are continuing to delay presentation to hospital for prolonged periods, according to a study published in the Archives of Internal Medicine. Robert J. Goldberg and colleagues at the University of Massachusetts Medical School in Worcester, USA, undertook a longitudinal study of 3837 patients hospitalized for AMI between 1986 and 1997.

\section{Significant findings}

They found that the mean, median and distribution of delay times showed either inconsistent or no changes over this time period. In 1986, the mean delay time was $4.1 \mathrm{~h}$, and the median $2.2 \mathrm{~h}$. Over a decade later, in 1997, no significant change had occurred; mean delay time was $4.3 \mathrm{~h}$ and median $2.0 \mathrm{~h}$. Overall, with no significant changes over time, only approximately 44\% of patients with AMI presented to hospital in less than $2 \mathrm{~h}$ of the onset of symptoms. The researchers found a number of factors that were associated with delays of more than $2 \mathrm{~h}$, including increasing age, history of angina or diabetes, onset of symptoms in the afternoon or evening, and hospitalization in the most recent study year (1997). The results of the study are of particular concern given the known time-dependent benefits associated with prompt use of coronary reperfusion strategies. The researchers found that as many as one in five AMI patients delayed their presentation by more than $6 \mathrm{~h}$, arriving at the hospital past the time when reperfusion therapy has its maximum benefit.

\section{Comments}


Goldberg commented that, although it is an understandable human reaction to deny and downplay the seriousness of these symptoms, healthcare professionals and the mass media have a duty to educate patients and their families on the need to seek care rapidly.

\section{Methods}

The researchers examined the time taken from onset of symptoms to presentation at hospital

\section{Additional information}

\section{References}

1. Goldberg RJ, Yarzebski J, Lessard D, Gore JM: Decade-long trends and factors associated with time to hospital presentation in patients with acute myocardial infarction: the Worcester Heart Attack Study. Arch Intern Med. 2000, 160: 3217-3223. 